\title{
DAPHNIPHYLLUM (DAPHNIPHYLLACEAE) IN PENINSULAR MALAYSIA
}

\author{
R. KIEW \& A.R. RAFIDAH \\ Forest Research Institute Malaysia, Kepong, Selangor, Malaysia
}

\begin{abstract}
SUMMARY
Three species of Daphniphyllum occur in Peninsular Malaysia: D. glaucescens Blume var. lancifolium (Hook.f.) T.C.Huang, D. laurinum (Benth.) Baill. and D. scortechinii Hook.f. Daphniphyllum glaucescens var. glaucescens and var. blumeanum (Baill. ex Müll.Arg.) J.J.Sm. do not occur in Peninsular Malaysia and specimens identified as such belong to D. glaucescens var. lancifolium.
\end{abstract}

Key words: Daphniphyllum, Peninsular Malaysia.

\section{INTRODUCTION}

There has been confusion concerning the number of Daphniphyllum species that occur in Peninsular Malaysia. Hooker (1890) recorded three species, D. lancifolium Hook.f, D. laurinum (Benth.) Baill. and D. scortechinii Hook.f. Ridley (1924) included another species, $D$. bancanum Kurz, in addition to the three species recorded by Hooker. Huang (1966) in his monograph of Daphniphyllum considered only two species to be present in Peninsular Malaysia, i.e. D. laurinum (with D. bancanum as a synonym) and D. glaucescens Blume with D. lancifolium and D. scortechinii being reduced to subspecies of the latter. Whitmore (1972) recognized two species, D. glaucescens and $D$. laurinum, but not the subspecies noting that "the form with blunt leaves may be distinguished as D. glaucescens ssp. scortechinii (Hook.f.) Huang, the other as D. glaucescens ssp. lancifolium (Hook.f.) Huang". Turner (1997) listed D. laurinum and D. glaucescens with D. lancifolium and D. scortechinii as synonyms of the latter. However, Huang (1997) in his Flora Malesiana account no longer recognized subspecies in D. glaucescens but reinstated Malesian taxa at specific rank, thus he considered both D. lancifolium and D. scortechinii as species. However, he retained var. blumeanum (Baill. ex Müll.Arg.) J.J.Sm. as a variety of D. glaucescens. Thus, the number of Daphniphyllum taxa he recorded for Peninsular Malaysia was five (four species, D. lancifolium, D. laurinum, D. scortechinii and D. glaucescens with two varieties, var. blumeanum and var. glaucescens).

In revising the genus for the Flora of Peninsular Malaysia, it became clear that, while D. laurinum and D. scortechinii are distinct species, it was difficult to distinguish the two varieties of $D$. glaucescens from $D$. lancifolium. The differences between these three taxa were therefore re-assessed based on specimens of var. glaucescens from Java, of var. blumeanum from Java and Sulawesi, from where the two varieties had 
Table 1. Differences between varieties of Daphniphyllum glaucescens and Peninsular Malaysian specimens identified as varieties of Daphniphyllum glaucescens and D. lancifolium.

\begin{tabular}{lccc}
\hline & \multicolumn{2}{c}{ Daphniphyllum glaucescens } \\
& var. blumeanum & var. glaucescens & $\begin{array}{c}\text { Peninsular Malaysian } \\
\text { D. glaucescens } \text { and D. lancifolium }\end{array}$ \\
\hline Infructescence length $(\mathrm{cm})$ & $7-10.5$ & $5.5-10.5$ & $(2.3-) 4-5.5(-7)$ \\
Fruit stalk length $(\mathrm{mm})$ & $12-15$ & $10-15$ & $5-10(-15)$ \\
Fruit surface & smooth & tuberculate & tuberculate \\
Stigmas in fruit & caducous & caducous & persistent \\
\hline
\end{tabular}

originally been described, and specimens identified as these two varieties from Peninsular Malaysia and as D. lancifolium.

Leaf characters were not useful in separating these taxa. However, a combination of fruit characters, especially stalk length and fruit surface previously used by Huang $(1996,1997)$, as well as infructescence length and persistence of the stigmas (Table 1) showed firstly that specimens from Peninsular Malaysia variously described as D. lancifolium, D. glaucescens var. glaucescens and var. blumeanum belong to a single taxon; and secondly that the Peninsular Malaysian taxon is distinct from either var. glaucescens and var. blumeanum, neither of which therefore occur in the Peninsula.

Using the characters in Table 1, Peninsular Malaysian specimens (var. lancifolium) are distinct from those of var. blumeanum (fruit surface smooth) and from both var. blumeanum and var. glaucescens using a combination of infructescence and fruit stalk lengths (generally shorter in Peninsular Malaysia specimens) and in the stigmas being persistent. The tuberculate surface of the fruits is the result of uneven shrinkage of the fruit wall on drying rather than to outgrowths of the fruit wall or state of maturity.

Although the Peninsular Malaysian population is distinct by a combination of these characters, it cannot be distinguished from the other varieties of D. glaucescens by characters of the leaf, female flower, and fruit size and shape. Therefore this taxon does not warrant specific rank and is accorded varietal status.

Hooker (1890), Ridley (1924) and Huang (1997) all based their descriptions of D. lancifolium on very few specimens, all from the type locality. Now that more specimens have been collected, a detailed description is provided, except for male flowers, which have yet to be collected.

Daphniphyllum glaucescens Blume var. lancifolium (Hook.f.) Rafidah, stat. nov.

Daphniphyllum lancifolium Hook.f. (1890) 354; Ridl. (1924) 235; T.C.Huang (1997) 160.

Daphniphyllum glaucescens Blume ssp. lancifolium (Hook.f.) T.C.Huang (1966) 165. - Daphniphyllum glaucescens Blume, Whitmore (1972) 182 p.p. - Daphniphyllum glaucescens Blume var. glaucescens auct. non T.C.Huang (1997) 156. - Daphniphyllum glaucescens Blume var. blumeanum (Baill. ex Müll.Arg.) J.J. Sm. auct. non Huang (1997) 156. - Type: King's Coll. 7010 (holo K), Perak, Gunung Hijau 'Gunong Ejau' alt. 4500-4600 ft. 
Shrub or tree $2-21 \mathrm{~m}$ tall, to $25(-40) \mathrm{cm}$ diameter. Bark smooth, red brown; inner bark brown to greyish brown. Sapwood pale to brownish white. Leaves clustered at the end of twigs; petioles slender, $1.5-4.5 \mathrm{~cm}$ long; blades lanceolate, (7-8.5-)11-17 by $2.5-4.5 \mathrm{~cm}$, thinly coriaceous, glossy, dark green drying blackish green, glaucous beneath, base cuneate, margins slightly revolute, apex acuminate; midrib prominent beneath; lateral veins 8-10 pairs, very fine and inconspicuous on both surfaces, intercostal veins reticulate. Male inflorescences unknown. Female inflorescences racemose with subumbels of up to 10 flowers at the tip, 2.5-6 cm long. Female flowers green, pedicels 5-15 mm long; calyx campanulate, 2-4 mm long, 3- or 4-lobed; staminodia present; ovary ellipsoid to globose, c. $2 \mathrm{~mm}$ long, stigmas bilobed, 1-1.5 mm long, strongly circinnate. Infructescences to $7 \mathrm{~cm}$ long. Fruits with stalks 6-16 mm long, calyx caducous, drupes pale green ripening purple, ellipsoid, $6-12.5$ by $5-10 \mathrm{~mm}$, tuberculate; stigmas persistent.

Vernacular name - Rasa (Malay).

Distribution - Daphniphyllum glaucescens is widespread in Malesia. Only var. lancifolium occurs and is endemic in Peninsular Malaysia (Perak, Kelantan, Terengganu, Pahang and Johor).

Ecology - In montane forests at 700-1600 m, usually on steep slopes of upper montane forest, sometimes common.

Note - When Hooker (1890) described Daphniphyllum lancifolium he cited King's Collector without a number but gave the detail 'Perak; alt. 4500-4600 ft.' The only King's Collector specimen at Kew is number 7010 and it has 'alt. 4500-4600 ft' written on the label. This is therefore the type. Huang (1966) was in error in citing King's Collector 7007 as the type, because firstly there is no duplicate of it at Kew, and secondly the label records a different altitude (4000-4600 ft).

Specimens examined:

PERAK. Bukit Larut FR, Gunung Hijau King's Collector 7007 (BM, L, SING), King's Collector 7010 (holotype K), Burkill \& Haniff SFN 12632 (KEP, SING), Whitmore FRI 12906 (K, KEP, L, SING); Bubu FR Symington FMS 30881 (KEP); Gunung Batu Puteh Wray 249 (SING). - KeLANTAN. Gunung Stong Symington FMS 37698 (K, KEP, SING); Gunung Rabong Soepadmo \& Mahmud 1131 (KLU, L, SING). - TerengGanu. Gunung Padang Moysey \& Kiah 31897 (KEP, SING), Whitmore FRI 12674 (KEP, L). - PAHANG. Cameron Highlands, Mentigi FR Chan FRI 16811 (KEP, L); Gunung Berembun Kochummen FRI 19087 (K, KEP, L); Ng FRI 5910 (K, KEP, L); Gunung Jasar Ogata KEP 110316 (K, KEP, L, SING); Gunung Batu Brinchang Whitty \& Henderson 18046 (KEP, SING); Tanah Rata Whitty \& Henderson 18006 (KEP, SING); Genting Highlands Whitmore FRI 3888 (K, KEP, L). - JoHOR. Gunung Chabang Tiga Samsuri \& Ahmad Shukor SA 717 (KEP); Gunung Belumut Holttum 10746 (KEP), Walker FMS 33845 (KEP).

\section{ACKNOWLEDGEMENTS}

This research was carried out as part of the Flora of Peninsular Malaysia Project (Project no. 01-04-01-0000 Khas) at the Forest Research Institute Malaysia funded by the Ministry of Science, Technology and Innovation (MOSTI). We are grateful to the curators of the Kew, United Kingdom; Natural History Museum of London, United Kingdom, Singapore Botanic Gardens; and University of Malaya, Kuala Lumpur, Malaysia herbaria for permission to examine specimens in their care. 


\section{REFERENCES}

Hooker, J.D. 1890. Daphniphyllum. Flora of British India 5: 353-354.

Huang, T.C. 1966. Monograph of Daphniphyllum. Taiwania 12: 137-232.

Huang, T.C. 1996. Notes on taxonomy and pollen of Malesian Daphniphyllum (Daphniphyllaceae). Blumea 41: 231-244.

Huang, T.C. 1997. Daphniphyllaceae. Flora Malesiana, Ser. I, 13: 145-168.

Ridley, H.N. 1924. Daphniphyllum. Flora of the Malay Peninsula 3: 234-235.

Turner, I.M. 1997 ('1995'). Daphniphyllaceae. Gard. Bull. Singapore 47: 183.

Whitmore, T.C. 1972. Daphniphyllaceae. Tree Flora of Malaya 1: 181-182. 